\title{
A xawara e os mortos: os Yanomami, luto e luta na pandemia da Covid-19
}

\section{The xawara and the dead: Yanomami people, mourning and fighting along COVID-19 pandemic}

\author{
Marcelo Moura Silva' \\ https://orcid.org/0000-0002-2105-8813 \\ mouramarcelosilva@gmail.com \\ Carlos Estellita-Lins ${ }^{\prime \prime}$, III \\ https://orcid.org/0000-0001-9509-1811 \\ carlos.estellita@icict.fiocruz.br \\ ' Museu Nacional/Universidade Federal do Rio de Janeiro - Rio de Janeiro, RJ, Brasil \\ Doutorando em Antropologia Social \\ " Fundação Oswaldo Cruz - Rio de Janeiro, RJ, Brasil \\ II' Museu Nacional/Universidade Federal do Rio de Janeiro - Rio de Janeiro, RJ, Brasil \\ Pesquisador associado
}




\title{
Resumo
}

A partir de uma etnografia das primeiras repercussões da pandemia do coronavírus entre os Yanomami, apontamos cruzamentos e tensões entre concepções nativas sobre a morte e a origem das doenças e discursos da epidemiologia e da biossegurança, sobretudo na imposição do sepultamento biosseguro dos corpos dos Yanomami vítimas da Covid-19. Acompanhamos algumas traduções da pandemia feita pelos Yanomami, na Terra Indígena Yanomami, destacando a correlação entre a categoria nativa xawara e a história do contato com os napë (brancos), principalmente no modo como a chegada de uma nova doença reativa a memória das epidemias do passado e reelabora os perigos da proximidade com os brancos. Por fim, ao redor dos excessos patogênicos dos cadáveres, discute-se uma equivocação controlada envolvendo as insistentes permanências dos vírus e dos pore (alma-fantasma) dos mortos. Buscou-se reconhecer os embates cosmopolíticos e a necessidade de traduções efetivas entre protocolos de biossegurança e a prática ritual dos funerais Yanomami, onde se mostra útil a adoção da hipótese do multinaturalismo para apresentar práticas compartilhadas na pandemia da Covid-19.

Palavras-chave: pandemia; etiologia Yanomami; ritos fúnebres; cosmopolítica.

\begin{abstract}
Provided an ethnography attentive to the first repercussions of the coronavirus pandemic among the Yanomami, we pointed out tensions and cross-overs between native conceptions about the origin of diseases or death and epidemiology or biosafety discourses, especially due to imposing biosecurity corpse burial rules on Yanomami victims of COVID-19. We did follow some pandemic translation efforts by the Yanomami, in the Yanomami Indigenous Land, highlighting the correlation between the xawara and the history of napë (whites) contact, focusing especially the way through which new disease arrival reactivates memories of past epidemics and re-enacts dangers of close proximity to white people. Finally, around the pathogenic excesses of the corpses, a controlled equivocation involving the insistent permanence of viruses and the pores (ghost soul) of the dead was discussed. We sought to recognize cosmopolitical clashes and a claim for effective translations between biosecurity protocols and the ritual practice of Yanomami funerals. It proved useful to adopt the hypothesis of multinaturalism to discuss shared practices in COVID-19 pandemic.
\end{abstract}

Keywords: pandemic, Yanomami etiology, funerary rites, cosmopolitics. 
Em 9 de abril de 2020 a pandemia do Sars CoV-2 se materializou nos corpos e na vida dos Yanomami. Nesse dia, registrou-se o primeiro óbito por Covid-19 entre os indígenas da etnia. Poucas horas depois de falecer em Boa Vista, na UTI do Hospital Geral de Roraima, a vítima - um adolescente da comunidade Helepe - foi enterrada sem consentimento dos familiares em um cemitério da mesma cidade, sob procedimentos emergenciais recomendados no protocolo de biossegurança do Ministério da Saúde e aplicados pelos Distritos Sanitários Especiais Indígenas (os DSEIs) da Secretaria Especial de Saúde Indígena (Sesai).

Quando a notícia passou a circular na floresta, um de nós estava junto dos Yanomami, na comunidade Maxokapiu. ${ }^{1}$ Desde declarada a pandemia no Brasil as informações chegavam pela conexão, via radiofonia, entre as comunidades e os Yanomami que acessavam o rádio na sede da Hutukara Associação Yanomami (HAY) em Boa Vista. As mensagens davam conta de deixar todos alertas, o antropólogo inclusive. Os números assustavam e aumentavam todos os dias. "A terra-floresta dos brancos vai ficar vazia" (napëpë urihi a prokëprario), diziam os interlocutores na cidade. Nos primeiros momentos as notícias eram recebidas com curiosidade e certa apreensão, mas, com a primeira morte e principalmente o enterro compulsório a que a vítima foi submetida, o medo se instalou entre os Yanomami.

Esse duplo fato, a morte pelo novo vírus e o sepultamento na cidade, inseriu os Yanomami na globalização das estatísticas da Covid-19 e escancarou o fosso de diferença entre a experiência local dessa cultura particular com a doença e a morte e as diretrizes e protocolos adotados por governos e instituições internacionais na administração do contexto pandêmico. Sendo compulsório, o enterro biosseguro enquanto medida de contenção ao vírus pode também ser caracterizado, assim como faz Stengers (2018) para embates cosmopolíticos, por uma "declaração de guerra" dos especialistas - políticos, governantes, legisladores, infectologistas e epidemiologistas - lançada contra aqueles cujas tradições são trazidas à cena para serem condenadas como possíveis vetores da propagação viral. Nos referimos à intraduzível violência que o enterro

1 Comunidade no médio curso do rio Demini, porção central da Terra Indígena Yanomami, onde um dos autores, Marcelo Moura Silva, realiza pesquisa, desde 2018, entre os Yanomami falantes do dialeto yanomae. 
de um parente morto, e o impedimento que o sepultamento cria para o ritual funerário reahu representam para o povo Yanomami e sua sociocosmologia. Em um texto recente, o antropólogo Bruce Albert (2020) expõe a questão: "Dispor de um defunto sem rituais funerários tradicionais constitui, para os Yanomami, como para qualquer outro povo, um ato inumano e, portanto, infame."

A "infâmia" se originou em um documento, bastante sui generis e talvez precipitado, do Conselho Nacional de Justiça. Precipitado porque foi o primeiro documento brasileiro acerca da pandemia, apenas seis dias após publicação análoga sobre o manejo de cadáveres, pela Organização Mundial de Saúde (OMS). Sui generis pois não considera aquilo que outros documentos buscam exprimir ao recomendar ações em saúde - de que modo fazer um enterro digno para a família e seguro para a comunidade. ${ }^{2}$ Não existe nenhuma recomendação que determine sepultamento ou cremação imediatos para as vítimas da Covid-19. Em Nova York proliferaram câmaras frigoríficas; em ambientes de pesquisa as necropsias têm sido praticadas; as recomendações admitem inclusive sepultamento local nas comunidades. ${ }^{3}$

Entre os Yanomami, a morte enseja o período de luto que se estende até o rito funerário reahu. A magnitude do evento, que articula um amplo espectro de fundamentos cosmológicos e da organização do ambiente sociopolítico (cf. Albert, 1985), demanda uma série de preparativos e protocolos, desde o cuidado com o corpo até a organização e o desenrolar do ritual. Resumidamente, os procedimentos para lidar com o corpo morto consistem em embrulhar o cadáver em palhas e içá-lo em uma estrutura posta alta nas árvores da floresta. Permanecerá em processo de putrefação, que objetiva separar a carne dos ossos. Os ossos, então, serão calcinados numa pira funerária junto aos pertences do morto, pulverizados e transformados em cinzas que serão condicionadas em cabaças. Estas, então, são seladas e só voltarão a ser abertas no momento

2 A portaria conjunta $\mathrm{n}^{\circ} 1$, de 30 de março de 2020 , assinada pelo corregedor nacional de Justiça e pelo ministro da Saúde, estabelece "procedimentos excepcionais para sepultamento e cremação de corpos", nas hipóteses de "ausência de familiares ou de pessoas conhecidas do obituado" ou em razão de exigência de saúde pública (Conselho Nacional de Justiça, 2020).

3 O documento aplicando o conceito de manejo seguro "safe manegement of a dead body" é de 24/03/2020 (World Health Organization, 2020). A importância do tema provém de febres hemorrágicas altamente contagiosas como o Ebola. Poderíamos dizer que os Krahó estudados por Manuela Carneiro da Cunha (1978) são especialistas nesse manejo seguro do corpo dos mortos. 
de fazer "desaparecer as cinzas" (poraximu). É o momento da realização do ritual propriamente dito, de chorar o morto junto aos corresidentes e visitantes. As cinzas serão, então, enterradas ou diluídas em mingau de banana para serem consumidas no ritual.

O reahu é algo de importância vital para os vivos, que administram as fronteiras e as dinâmicas de distanciamento e aproximação entre vivos e mortos, parentes e afins, aliados e inimigos (Albert, 1985) ao trabalharem o luto chorando, coletivamente, as relações do morto em vida. Mas o reahu é, também, fundamental para os mortos que podem, enfim, percorrer a trilha final para a vida póstuma. Os Yanomami contam que, na morte, os componentes imateriais da pessoa se desprendem do corpo para se transformarem nos pore, almas-fantasmas dos mortos cujo destino, após a vida, é uma aldeia na floresta acima das costas do céu.

Sobretudo, o reahu permite o esquecimento. Fazer desaparecer as cinzas e a memória do morto é conjurar a possibilidade de sua permanência no mundo dos vivos e de um possível retorno para atrair seus parentes para si, levando-os à doença e à morte. Desse modo, o enterro biosseguro ao fazer permanecer o morto, além de ser um fato revoltante e uma dor profunda para os parentes, representa um desequilíbrio perigoso entre o mundo dos vivos e dos mortos, atualizado na agência patogênica da saudade e dos pore. Até outubro de 2020, foram 11 casos de sepultamentos, em um quadro estatístico para a Terra Indígena Yanomami (TIY) de 10 mortes confirmadas e 13 suspeitas para a Covid-19, dentro de 1.202 casos de contaminação confirmados. ${ }^{4}$ Ao lado do combate à propagação do vírus em suas terras, se inaugura uma contenda jurídica, política, ética, cosmopolítica, ao redor da intenção dos Yanomami de retomarem os corpos de seus parentes vítimas da pandemia.

Muito se discutiu, durante as iniciativas de cooperação do movimento global health, ${ }^{5}$ sobre a real possibilidade de acordos ou de algum impacto

4 Ver Machado et al. (2020) para um panorama dos efeitos da pandemia na TIY, além do monitoramento divulgado pela Rede Pró-Yanomami e Ye'kwana (https://www.facebook.com/ RedeProYanomamiYekwana/).

5 O termo descreve três aspectos articulados constituindo um movimento forte na primeira década do século XXI: a incorporação de iniciativas de medicina tropical e saúde internacional europeias; interesse investigativo anglo-saxão; e cooperação de ONGs, Banco Mundial e agências de fomento internacionais com a OMS/WHO. Trata-se de uma tentativa de fazer ponte entre hemisfério norte e sul no interesse de uma agenda de saúde globalizada. 
na aliança da medicina baseada em evidências com os saberes tradicionais baseados em "iminências". Há posições matizadas, apostas relativistas e algum saudável ceticismo de etnólogos quanto ao caráter pouco saudável do diálogo tecnológico mobilizado na ocasião. Uma vez perdido o elã dessas megainiciativas e igualmente destruída a rede de prevenção e preparedness das pandemias asiáticas, restou ao mundo neoliberal do Antropoceno apenas a lição do Ebola: impeça circulação, faça quarentena, saiba que vai morrer, morra de medo e sepulte o cadáver bem lacrado! Nossa questão passa a ser de que modo uma decisão político-jurídica sobre os corpos dos Yanomami pode, ao mesmo tempo, "ser ativamente protegida da ficção segundo a qual os seres humanos de boa vontade decidem em nome do interesse geral" (Stengers, 2018, p. 459) e propor um tipo de reflexão que coloque o problema em presença daqueles corpos e almas que correriam o risco de serem enquadrados sob a lógica do bem comum e verem suas reivindicações desqualificadas como "interesses egoístas" dentro de uma crise generalizada.

É a partir de uma reflexão sobre disputas ao redor do vírus, suas origens, caminhos e permanências, e de uma etnografia dos primeiros efeitos da pandemia entre os Yanomami, que destacamos as relações político-etiológicas entre vivos e mortos, indígenas e não indígenas, situando a pandemia desde um ponto de vista Yanomami. Contudo, essas relações se veem também atravessadas pelos discursos científicos emergentes sobre as relações entre humanos e não humanos. Buscamos refletir sobre os problemas levantados nesse entrecruzamento das ontologias modernas e indígenas, que poderiam ser pensadas enquanto um mal-entendido acerca da natureza e seus limites cósmicos. De um lado, o povo Yanomami tentando resolver um problema provocado pela $x a w a r a,{ }^{6}$ trazida pelos brancos. De outro, os brancos colecionadores de vírus investigam de que modo essa "espécie" inesperada teria pulado do animal selvagem para o mercado humano.

\section{Etiologia e história}

A militância político-textual de Davi Kopenawa e Bruce Albert anunciava a queda do céu e a peste. Como pensar esse "acontecimento"? Além das camadas

6 Termo utilizado pelos Yanomami para traduzir o conceito de epidemia, além de se referir a doenças infecciosas contagiosas (ver Kopenawa; Albert, 2015, p. 613). 
de discussão sobre mito, história e equívoco na tradução, pensamos na morte como matéria semiológica/signalética por traduzir. A profecia xamânica foi aproximada de uma advertência ecológica e de uma sabedoria étnica. Como dimensionar seu caráter profético? Escatologia, sim, mas também teoria do fim, da morte e do esquecimento em outras acepções? Militantes verdes do Antropoceno entendem que BAU - business as usual - chega ao fim com o desequilíbrio mundial por recessão econômica. Já pensadores de modos de vida, como Latour, propõem que se pense no fim e se pratique alguns fins de mundo. Kopenawa e outros pensadores indígenas, como Ailton Krenak, nos pedem que adiemos o fim, evitemos a queda do céu. A possibilidade da comunicação de experiências de fim de mundo parece notável e pertinente. Por outro lado, os pedaços do céu que parecem cair na pandemia não se apresentam, para os Yanomami, como evento ou acontecimento do tipo fim do mundo - como para os brancos -, e eles apreendem essa nova xawara como mais uma doença do arsenal dos brancos.

A pandemia chegou na TIY primeiramente como notícia. Os Yanomami na cidade transmitiam as informações do avanço do vírus no mundo e no Brasil. Os informes geravam uma enorme audiência, pessoas corriam para se reunir ao redor do rádio para ouvir as palavras sobre a nova doença. Desde outras comunidades, centenas de pessoas interagiam na mesma frequência. $\mathrm{O}$ modo como a doença havia se alastrado no mundo, o alto grau de letalidade e a rapidez com que agia, os grupos de risco, a falta de remédios e as incertezas das pesquisas médicas eram elementos enfatizados para mostrar como os brancos estavam com medo: "Hoje os brancos... eles estão com medo, porque eles não sabem/ conhecem." Nessas conversas, a Covid-19 passou a ser conhecida por suas traduções em yanomae: hewë e opo xawarapë, epidemias do morcego e do tatu.

Queremos nos deter brevemente sobre essa tradução para considerar o rendimento da categoria etiológica xawara para uma reflexão sobre como os Yanomami interpretam sua relação com os brancos. É pela tradução xawara/ epidemia que percebem o coronavírus não como um evento de exceção e singularidade, mas como outro desdobramento histórico do caráter essencialmente patogênico dos napë e do perigo que representam seus vírus e práticas. Essa correlação entre brancos e poderes patogênicos se constrói desde os primeiros anos de contato, em função da coincidência da chegada dos napë e o aparecimento das epidemias. 
Ampla por definição, a classificação xawara compreende doenças de origem exógena, vorazes e devastadoras. Ao longo das últimas décadas a categoria - além de reter uma informação sobre a posição dos brancos em relação aos Yanomami - tem sido agenciada para dar conta da sucessão dos eventos epidêmicos (Albert, 1992, 2002). Apesar de estarem essencialmente atreladas aos napë como vetores, as epidemias xawara ganham outras classificações, que informam a especificidade dos agentes e eventos que lhes são causa. Em A queda do céu, Davi Kopenawa apresenta uma exegese epidemiológica onde encontramos, por exemplo, a "epidemia do padre", a "epidemia do Oswaldo", a "epidemia do helicóptero", também conhecida como epidemia do Werihi sihipi u (Kopenawa; Albert, 2015, p. 307-309).

É nesse inventário de enfermidades do contato que se acomodou a Covid-19. É xawara por sua voracidade e por seu vetor: os napë. Os classificadores hewë (morcego) e opo (tatu), efeitos de traduções similares às anteriores, tomam índices das reflexões epidemiológicas napë, para interpretá-los em elaborações xamânicas. Quando indagados sobre o porquê "do morcego" (hewë xawara a), os Yanomami respondiam - considerando as notícias que recebiam no rádio - que essa xawara havia começado porque, em uma terra muito distante, as pessoas teriam o hábito de comer morcegos. Ora, para os Yanomami comer morcegos é algo reprovável, atividade que só poderia estar relacionada a um povo desconhecido, sobre quem é possível projetar qualquer especulação sobre a diferença. Ademais, uma perspectiva sobre a relação entre doenças e a não observação de determinadas restrições culinárias não é, de modo algum, estranha aos Yanomami. Para citar um exemplo, quando estão grávidos, os casais Yanomami passam a observar uma dieta que os priva de comer carne de caças e peixes "grandes". Explicam que com isso evitam os ataques dos espíritos animais, vingativos e poderosos, que provocariam o adoecimento e a morte da mãe ou do bebê.

Que a pandemia tivesse sido desencadeada por um desequilíbrio alimentar ao redor dos morcegos parecia, assim, perfeitamente condizente com as etiologias Yanomami. Porém a segunda classificação da xawara em uso, "do tatu", sugere um deslocamento de uma apreciação culinária comum: o tatu é item no cardápio de caças Yanomami. O que os Yanomami relacionavam ao tatu não era uma prática alimentar execrável, mas outra atitude condenável dos napë, também diretamente associada à gênese do infortúnio atual. Assim como os tatus, há um tipo de inimigo, infelizmente, bem conhecido pelos Yanomami, 
que é notável por sua capacidade de cavar buracos: o garimpo. "Tatuzão" é como os Yanomami se referem, em português, aos grandes empreendimentos do garimpo ilegal em suas terras. Associados aos desequilíbrios ambientais do extrativismo desenfreado, a presença do tatu na tradução Yanomami da pandemia se relaciona com outra elaboração xamânica sobre a gênese das xawara, por estarem associadas aos minérios: ambos foram enterrados pelo demiurgo Omama no tempo mítico. É dos minérios expostos nos enormes buracos dos garimpeiros que emanam os eflúvios patogênicos das epidemias (cf. Albert, 1992, 2002; Kopenawa; Albert, 2015).

\section{Traduzindo a pandemia}

A construção de sentido ao redor da hewë/opo xawarapë se dava a todo tempo: nas conversas entre as pessoas no cotidiano da casa e do trabalho, em reuniões com lideranças de outras comunidades e também na relação com os profissionais de saúde que trabalham na floresta. Passou a ser um assunto recorrente da prática xamânica na busca por negociação com os espíritos responsáveis por esse novo mal e, particularmente, se tornou assunto dos discursos hereamu. O hereamu, proferido à noite ou na aurora da manhã, é o momento em que homens e mulheres expõem seus pensamentos ao grupo desde a praça central da grande casa circular. No período da pandemia, servia também para que fossem transmitidas as informações e reflexões sobre a xawara. À noite, uma das lideranças da comunidade, Geraldo Yanomami, falava da xawara e das notícias que ouvia pelo rádio. $\mathrm{O}$ que se segue são traduções para o português de suas palavras:

Hoje, na cidade, os brancos não estão trabalhando. Eles estão ficando somente dentro de suas casas. [...]. Por isso, eles enviaram suas palavras para nós: “Awei, pra vocês Yanomami continuarem vivendo com saúde vocês não vão para Barcelos." Porque eles estão preocupados. Essa epidemia não é fraca. Ela é muito

7 Município do estado do Amazonas e principal via de acesso dos Yanomami da região do rio Demini ao mundo dos brancos. 
forte mesmo. [...] Nós moramos numa única casa, por isso [se a doença chegar] em um só dia nós vamos acabar. Assim que vai acontecer.

[...] Eles não sabem, hoje as palavras não estão claras. Enfermeiros, médicos, todos eles não sabem. As palavras não são claras. Todos eles vão morrer. Eles podem acabar. Por causa da epidemia do morcego. Não tem remédio para ela. Porque ela é diferente. Só tinha vacina para a epidemia do porco [gripe suína]. Hoje não tem vacina. Nós podemos acabar.

Aqui, há uma consideração da situação das cidades e o fato dos napë estarem acossados em suas casas pelo vírus para o qual não têm remédio. O medo de sair para trabalhar é análogo a situações bem conhecidas pelos Yanomami, e enfatizá-lo é um modo de traduzir a pandemia aos termos nativos. Em diferentes momentos da vida Yanomami sair de casa (para roça, para floresta, etc.) é se fazer visível aos inimigos e seus ataques, principalmente em momentos de instabilidade como nos casos dos ritos de reclusão, de doença e de conflitos. São contextos em que ficar em casa é imperativo para uma sobrevivência saudável. Agora, era a vez dos napë entrarem em reclusão.

Em certo momento de seu discurso Geraldo passa a refletir sobre o modo como a doença seria mais grave nas pessoas mais velhas. A nova xawara vitimaria principalmente os mais fragilizados pelo tempo e por outras doenças. Nesse ponto, receoso, Geraldo percorre sua memória das epidemias do passado:

No passado eu já adoeci. Hoje talvez eu adoeça, eu não sei, não está claro. Pois eu já adoeci muitas vezes por causa das epidemias. Eu adoeci com a epidemia do Werihi sihipi u quando eu era criança. Mas eu me recuperei. Eu me recuperei, mas quando fizeram a estrada eu adoeci de novo. Eu me recuperei novamente, mas eu adoeci de novo quando a epidemia do filho do Kixi chegou. Assim aconteceu comigo, por isso, hoje, eu não aguentaria.

Nesse trecho, o vemos elencar três graves epidemias que acometeram os Yanomami nos primeiros anos de contato. Relembrar esses eventos marca não só o medo das comorbidades, mas, principalmente, conecta a xawara de hoje às do passado por suas origens: os brancos. Refletindo então sobre a necessidade de manterem-se afastados dos brancos, Geraldo faz uma observação sobre a 
portaria da Funai ${ }^{8}$ que, segundo os avisos da Hutukara, proibia a entrada de não indígenas em seu território: "Vocês brancos não devem mais ir à floresta dos Yanomami." E adiciona: "O governo proibiu, mas eu não sei. Só lá onde estão os garimpeiros que [os brancos] vão chegar. Só eles vão chegar de verdade." Como vimos, os Yanomami enxergam no rastro de destruição da floresta - os enormes buracos escavados pelos garimpeiros - os índices da chegada da xawara que emana dos minérios.

Hoje, em uma matemática mortal, o contexto da TIY é de assombro e medo pela soma pandemia + invasão. Desde 2019, as atividades do garimpo ilegal voltaram a atingir contornos catastróficos, na esteira da ascensão ao poder de um discurso anti-indígena que é, ao mesmo tempo, permissivo e propulsor às violações dos territórios e direitos indígenas. No período da pandemia, o drama da invasão se acentua na medida em que as regiões da TIY mais afetadas pelo coronavírus são, justamente, onde se concentram os principais fluxos da invasão (Machado et al., 2020). De certo modo poderíamos imaginar um tatu grande demais para comer ou caçar, que despeja dejetos prateados de um metal líquido e altamente venenoso: o mercúrio, necessário para extração de ouro.

Curiosamente, lidamos com elementos da tabela periódica e com formas de vida minimalistas que engendram desterritorializações longas e violentas. Ao derreter o gelo dos polos fabricamos desertos. Ao acelerar os contatos com a pletora de vírus nos reservatórios dos mamíferos selvagens criamos zoonoses. O pulo entre espécies característico das zoonoses - termo antropocêntrico ao extremo $0^{9}$ - arrasta transformações-devires conectando humanos atuais, laboratórios, fábricas de vacina, morcegos desconhecidos, pangolins e tatus. O esforço de fazer que os vírus falem é permanente, pois são actantes cuja intromissão no tribunal das coisas depende de tradução pelos cientistas versados em biologia molecular.

As interpretações da nova xawara partiam das informações que chegavam na floresta, traduções das notícias que circularam na cidade. A etiologia xamânica das napë-noses se reorganiza em um diálogo tradutivo com a etiologia científica das zoo-noses. Para os Yanomami, o desequilíbrio das relações humanas

8 Portaria n 419, de 17 de março de 2020 (Fundação Nacional do Índio, 2020).

9 Deveríamos pensá-las como "exfermidades"? Enfermidades que nos abrem para a exterioridade radical, a partir da intimidade multicausal, em apropriação perspectivista. 
com os animais e o meio ambiente está tematizado, assim como na mirada epidemiológica dos napë. Contudo, na etiologia Yanomami os brancos, humanos, são os vetores. É importante admitir a ideia de que os Yanomami se veem em contato com uma criação espúria de animais danosos e trazida pelos brancos. Nesse sentido, um vírus não é muito diferente de uma flechinha, dardo, ou um pequeno, e violento, espírito xamânico da floresta. $O$ fato é que um não humano e não vivo é bastante letal, capaz de viver no curto espaço de tempo do contato entre humanos e criar disputas acerca das maneiras de morrer.

Como apontam virologistas, a catástrofe climática pode estar ligada ao desenvolvimento de zoonoses desconhecidas (Keck, 2020) como a pandemia de Covid-19. A grande extinção dos animais, as migrações dos viventes e novas condições/situações instáveis engendram problemas inéditos. Uma aparente simplificação do planeta é, contudo, paradoxalmente sacudida por ecologias microscópicas em permanente transformação e que falam em favor de um multinaturalismo. As políticas da xawara, expressas na disputa acerca dos sepultamentos de biossegurança, é um caso privilegiado para reflexão.

\section{Os excessos dos mortos}

Quando a notícia do primeiro caso de morte de um Yanomami chegou na floresta, as elaborações sobre a xawara do morcego/tatu ganharam contornos dramáticos. A ansiedade se erigia ao redor da nova enfermidade, mas, sobretudo, era a perspectiva do sepultamento que causava espanto. Diante dessa possibilidade, muitos Yanomami afirmavam que recusariam tratamentos médicos na cidade, contaminados por Covid-19 ou não. Nessa mesma tensão se viam os Yanomami internados na Casa de Apoio à Saúde Indígena (Casai) em Boa Vista. Em vídeos-protestos que fizeram circular nas redes, exigiam serem levados de volta para suas comunidades com medo, principalmente, de serem enterrados na cidade: "Nós queremos lidar com os mortos da forma própria e correta dentro de nossa cultura. [...] Aqui nessa terra, vocês fazem as coisas atrapalhadas conosco, nós não queremos que vocês nos enterrem!"10

10 Fala de uma das lideranças parcialmente reproduzida no vídeo-protesto divulgado pela Rede Pró-Yanomami e Ye’kwana nas mídias sociais (ver Liderança..., 2020). 
Delineamentos propostos por uma "antropologia das epidemias" destacam o modo como os protocolos universais e as ações emergenciais de combate aos surtos epidêmicos, ao inscreverem as doenças infecciosas em uma linguagem de medo e risco, acabam por normalizar técnicas e práticas administrativas que tomam os indivíduos infectados, vivos e mortos, como uma ameaça ao ordenamento público (Elbe, 2008). Na coletânea The anthropology of epidemics, organizada por Ann H. Kelly, Frédéric Keck e Christos Lynteris (2019), os autores apontam para a importância de uma investigação antropológica dos surtos epidêmicos justamente como forma de questionar os diferentes impactos sociais desses eventos. Assim, demonstram como as repostas epidemiológicas tendem a desconsiderar as práticas nativas locais exceto para as enquadrarem como rotas de transmissão do vírus.

Dado o caráter emergencial das epidemias, os protocolos de biossegurança acabam por "promover o pretexto para a extensão do poder governamental sobre todas as formas de vida e modos de viver" (Keck; Kelly; Lynteris, 2019, p. 4, tradução nossa). É preciso atentar para como a aplicação de protocolos biosseguros universais, no momento em que se inserem em contextos culturais particulares, tendem a promover uma argumentação ao redor do caráter eminentemente insalubre de determinadas práticas de cuidado e ritos funerários nativos, contribuindo para uma estigmatização colonialista que acaba por aprofundar os impactos das epidemias. Nessa retórica de guerra, o impedimento dos ritos funerários tradicionais - e o modo como isso afeta a relação dos vivos com seus mortos - é mera causalidade em um contexto em que a presença do vírus eclipsa outras permanências.

Em particular, destacamos a "ansiedade ao redor dos funerais tradicionais" e a ênfase nos cadáveres infectados como objetos de intervenção pública (Keck; Kelly; Lynteris, 2019, p. 11, tradução nossa) quando o cadáver epidêmico passa a ser visto como um perigo social em sua aliança com o inimigo público, o vírus. Falando sobre o efeito estigmatizante das narrativas sobre os ritos funerários tradicionais no contexto do Ebola, Lynteris e Evans (2019) propõem uma abordagem que interpreta o corpo morto não somente como um objeto a ser administrado, mas como um processo, um agente disruptivo em produção e disputa, de modo que se possam considerar as demandas que esses fazem para a sociedade.

Nessa decisão, que é integralmente política, o que "sobra" no enterro forçado dos Yanomami é todo o espectro de violência contra os corpos e almas, as 
famílias e comunidades, contra todo um povo, suas concepções de mundo, da vida, da morte. Afastar um povo de seus mortos é ameaçar suspender os alicerces da estruturação simbólica do ordenamento cosmológico e da agência dos sujeitos no mundo. Na América indígena, como já demonstravam Carneiro da Cunha (1978) e Viveiros de Castro (1986), a separação entre vivos e mortos tem, muitas vezes, um papel mais relevante na construção da ideia de humanidade do que a separação entre humanos e animais. Desagregar tal fronteira representa um risco grave sobre a possibilidade de reprodução da própria sociedade enquanto coletivo humano. Para os Yanomami, enquanto as cinzas dos mortos não desaparecem, sua permanência ressurge como a causa insistente de possíveis doenças e mortes. $O$ desequilíbrio da relação entre vivos e mortos resultante nesse resíduo é o excesso patogênico dos pore que o reahu quer eliminar, desaparecendo corpo e memórias. Assim, o enterro biosseguro compulsório é não só uma ofensa ao morto e aos seus parentes, mas uma desestabilização perigosa da separação entre vivos e mortos cuja falência é um "prenúncio do fim da sociedade" (Smiljanic, 2002).

A chegada dos missionários salesianos entre os Yanomami da região do rio Cauaburis criou um problema semelhante ao redor da prática do sepultamento. Como aponta Smiljanic, as primeiras tentativas de enterrar cadáveres impostas pelos salesianos foram frustradas pela resistência dos Yanomami que "reagiram, desenterrando o corpo, realizando a cremação e deixando claro aos missionários que eram contrários a essa prática." (Smiljanic, 2002, p. 147). Como aponta a autora, a introdução de funerais do tipo cristão resultou no arrefecimento das práticas rituais nessa região, acarretando uma série de conflitos imediatos e repercussões a longo prazo no relacionamento interno dos grupos e entre as diferentes comunidades. Ademais, os Yanomami do rio Cauaburis também passaram a enfrentar os incômodos causados pelos inúmeros fantasmas dos mortos que vagam na floresta e nas aldeias.

Nesse mesmo plano de violência sobre os mortos e os rituais funerários dos Yanomami, lembremos ainda da famosa polêmica envolvendo as amostras de sangue coletada entre os Yanomami na Venezuela e no Brasil, pela equipe do geneticista James Neel e o antropólogo Napoleon Chagnon em 1967. Albert (2006) descreve a consternação dos Yanomami ao descobrirem, nos anos 2000, a existência de seu sangue ainda armazenado em laboratórios. Entre as pessoas cujo sangue havia sido coletado, muitos já estavam mortos. Foi só em 2015 que repatriaram as amostras e puderam, enfim, chorar os mortos e desaparecer 
com os vestígios que ainda permaneciam no mundo dos vivos. Na aldeia Piaú, na região do Toototobi, foi realizado o reahu. Na cerimônia, depois de chorarem a lembrança dos falecidos os xamãs, de luvas cirúrgicas, despejaram o conteúdo das amostras em um buraco cavado no chão da casa. ${ }^{11}$

Realizar um reahu para desaparecer ampolas de sangue quase 50 anos depois de terem sido coletadas (indevidamente) ilustra, de maneira suficiente, a importância inegociável do rito e o modo como os Yanomami estão dispostos a adaptarem-se para remediar o sofrimento causado pela retenção de seus mortos pelos napë. Apesar das idiossincrasias desse reahu específico, trataram de encerrar o luto e puderam, também, apaziguar e cuidar dos pore ofendidos pela permanência forçada no mundo dos vivos. No contexto da pandemia da Covid-19, os Yanomami impedidos de realizar o funeral de seus parentes serão, novamente, obrigados ao luto estendido, permanecendo expostos aos maus tratos da saudade e dos pore.

\section{Conclusões}

Na disputa ao redor do sepultamento dos Yanomami, o resíduo patogênico que a biossegurança quer extirpar é qualquer possibilidade de permanência do vírus. O excesso que os Yanomami querem por sua vez eliminar é a permanência, também patogênica, dos mortos no mundo dos humanos vivos. O que se revela é que ambos os lados argumentam pelo perigo do morto em relação ao ordenamento social, contudo estão em relação de equivocação (Viveiros de Castro, 2004), já que o que está em disputa é o desequilíbrio provocado pelas permanências do cadáver - os vírus e os pore. Um interpreta o morto como o perigo a ser administrado para impedir a transmissão do vírus, ainda que isso signifique despi-lo de humanidade; o outro advoga para o fato de que a violação do rito funerário é motivo de um desordenamento ainda mais profundo. Se a morte procede um rasgo no tecido das relações, o impedimento da despedida com os procedimentos corretos é outra dilaceração nessa rede de afetos e responsabilidades entre os vivos e os pore.

11 Para uma descrição detalhada, ver Souto Maior e Benfica (2015). 
O problema da presença e passagem do vírus nos corpos dos vivos e dos mortos acaba por traduzir um desequilíbrio fisiológico em um amplo espectro de distúrbios sociocosmológicos. É preciso, urgentemente, reconhecer a particularidade das experiências indígenas nesse contexto, pois há um abismo insuportável entre a imposição de adaptações biosseguras e a violência de impedir totalmente o cuidado apropriado para com os mortos e o trabalho de luto para os vivos. Nesse sentido, o que se impõe como ferramenta em tal disputa é, necessariamente, um agenciamento político das traduções. Cabe apostar nelas de modo que conduzam a algum controle desses equívocos e sejam capazes de comunicar os termos em causa. Discussões e decisões devem dispor não só da definição objetiva de um vírus, mas também das perspectivas daqueles cujas vidas e práticas se entrecruzaram com o vírus, a enfermidade viral e o acontecimento produzido. No contexto em que nos debruçamos aqui, uma consulta aos cadáveres epidêmicos precisa ser acompanhada de uma consulta aos Yanomami e às almas de seus mortos, para que, no fim, a questão não seja resolvida tendo como mera referência um "mínimo de danos" que não permite enxergar toda a gama de sofrimentos envolvidos.

Por cosmopolíticas, entre outras coisas, Isabelle Stengers (2003, 2018) entende as incógnitas de uma questão relativa à "ecologia das práticas". Cabe evitar tanto o elogio da ciência pura quanto a denúncia das técnicas (sempre buscando e sempre desprovidas de ética e valores) - aceitando uma diáspora de práticas. Para o etnólogo, assim como para o antropólogo das ciências, é pertinente perceber a natureza múltipla, não unificada, se dizendo de várias maneiras e tentar reconhecer uma guerra sincopada por negociações diplomáticas, que articula cosmologias pré-modernas no interior de impasses das ciências modernas. Isso ocorre na diplomacia política dos cadáveres sujeitos ao sepultamento sob regras máximas de biossegurança, que opõe rituais fúnebres Yanomami - produtores de uma floresta cheia de mortos e vivos sob cosmopolíticas intensivas - aos cuidados desgovernados da nação branca brasileira - imitadora de truques científicos cuja justificativa por vezes lhe escapa.

Há exigência de simetria absoluta entre duas formas de sepultamento distintas. Distintas não por se tratar de culturas que administram cadáveres diferentemente, mas, ao contrário, por fazerem surgir distintos vírus e enfermidades de acordo com naturezas distintas e incomensuráveis. Em uma delas o antigo jirau elevado aos céus, onde o cadáver iria esperar empoleirado para 
reduzir-se aos ossos, a serem cremados e depois "desaparecidos" de acordo com ritos prolongados e cuidadosos. Noutra cena, reinam os envoltórios desenvolvidos para necrotério, feitos de polímeros plásticos absolutamente lacrados, com instruções de assepsia e regras sobrepostas às prescrições religiosas (de acordo com o relativismo cultural) desde que o corpo, fábrica de vírus, fique completamente isolado com seus produtos infectantes. $\mathrm{O}$ cientista protetor exclusivo dos vivos recomenda/obriga um percurso simples, localizado e discreto. A teoria da infecção só enxerga a luta imunológica do organismo contra moléculas vivas estranhas. Não se trata de pressupor ou buscar a paz perpétua das ciências, mas de deixá-las em suspenso enquanto ecoa um sussurro do tipo "há algo de mais importante em causa".

Nesse momento, há algo de muito mais importante em causa e não se trata de sussurrar, mas de ecoar um grito pela dignidade dos vivos e dos mortos, para dar voz aos ameaçados, para que os experts compreendam que suas decisões são, também, uma declaração de guerra. "O que aqui importa é a proibição do esquecimento, ou pior, da humilhação" (Stengers, 2018, p. 462). Proibir que nós, brancos, esqueçamos os cadáveres dos Yanomami e a humilhação de mantê-los enterrados. Impedir a invasão, humilhação e violência sobre sua floresta, seus corpos, pensamentos e modos de viver e morrer, para que eles possam, enfim, fazer esquecer seus mortos.

\section{Referências}

ALBERT, B. Temps du sang, temps des cendres: représentation de la maladie, système rituel et espace politique chez les Yanomami du sudeste (Amazonie brésilienne). 1985. Tese (Doutorado) - Université de Paris X, Paris, 1985.

ALBERT, B. A fumaça do metal: história e representações do contato entre os Yanomami. Anuário Antropológico, Rio de Janeiro, n. 89, p. 151-190, 1992.

ALBERT, B. O ouro canibal e a queda do céu: uma crítica xamânica da economia política da natureza (Yanomami). In: ALBERT, B.; RAMOS, A. R. (org.). Pacificando o branco: cosmologias do contato no Norte-Amazônico. São Paulo: Unesp, 2002. p. 239-276.

ALBERT, B. "Freezer anthropology" e bioética: o caso do sangue yanomami. In: POVOS indígenas no Brasil 2001/2005. São Paulo: Instituto Socioambiental, 2006. p. 337-340. 
ALBERT, B. Yanomami: mortos sem sepultura. In: N-1 EDIÇÕES. Pandemia crítica (27). São Paulo: n-1 edições, 2020. Disponível em: https://www.n-ledicoes.org/textos/60. Acesso em: 31 ago. 2020.

CARNEIRO DA CUNHA, M. Os mortos e os outros. São Paulo: Hucitec, 1978.

CONSELHO NACIONAL DE JUSTIÇA. Portaria conjunta $n^{\circ} 1$, de 30 de março de 2020. Estabelece procedimentos excepcionais para sepultamento e cremação de corpos durante a situação de pandemia do Coronavírus, com a utilização da Declaração de Óbito emitida pelas unidades de saúde, apenas nas hipóteses de ausência de familiares ou de pessoas conhecidas do obituado ou em razão de exigência de saúde pública, e dá outras providências. Brasília: CNJ, 2020.

ELBE, S. Risking lives: AIDS, security and three concepts of risk. Security Dialogue, London, v. 39, n. 2-3, p. 177-198, 2008.

FUNDAÇÃO NACIONAL DO ÍNDIO. Portaria n 419/PRES, de 17 de março de 2020. Estabelece medidas temporárias de prevenção à infecção e propagação do novo Coronavírus (COVID-19) no âmbito da Fundação Nacional do Índio - FUNAI. Boletim de Serviço da Funai, Brasília, ed. extra, p. 1, 17 mar. 2020. Disponível em: http:// www.funai.gov.br/arquivos/conteudo/cogedi/pdf/Boletim\%20de\%20Servicos/2020/ Boletim\%20Edicao\%20Extra\%20de\%2017.03.2020.pdf. Acesso em: 27 ago. 2020.

KECK, F. Avian reservoirs: virus hunters and birdwatchers in Chinese sentinel posts. Durham: Duke University Press, 2020.

KECK, F.; KELLY, A. H.; LYNTERIS, C. Introduction: the anthropology of epidemics. In: KELLY, A. H.; KECK, F.; LYNTERIS, C. (ed.). The anthropology of epidemics. London: Routledge, 2019. p. 1-24.

KELLY, A. H.; KECK, F.; LYNTERIS, C. (ed.). The anthropology of epidemics. London: Routledge, 2019.

KOPENAWA, D.; ALBERT, B. A queda do céu: palavras de um xamã yanomami. Trad. Beatriz Perrone-Moisés. São Paulo: Companhia das Letras, 2015.

LIDERANÇA Yanomami, CASAI. 1 vídeo (1min29s). [S. l.]: Rede Pró-Yanomami e Ye'kwana, 16 jun. 2020. Instagram: @proyanomami_yekwana. Disponível em: https://www.instagram.com/tv/CBguqDtFySr/?igshid=1keoblhx83r5o. Acesso em: 27 ago. 2020.

LYNTERIS, C.; EVANS, N. H. A. Histories of post-mortem contagion: infectious corpses and contested burials. Cham: Palgrave Macmillan, 2019. (Medicine and Biomedical Sciences in Modern History Book Series). 
MACHADO, A. M. et al. (org.). Xawara: rastros da Covid-19 na Terra Indígena Yanomami e a omissão do Estado. São Paulo: Instituto Socioambiental, 2020.

SMILJANIC, M. I. Os enviados de Dom Bosco entre os Masiripiwëitheri: o impacto missionário sobre o sistema social e cultural dos Yanomami ocidentais (Amazonas, Brasil). Journal de la Société des Américanistes, Nanterre, n. 88, p. 137-158, 2002. Disponível em: http://jsa.revues.org/document2763/html. Acesso em: 27 ago. 2020.

SOUTO MAIOR, A. P. C.; BENFICA, E. Yanomami enterram as primeiras amostras de sangue repatriadas dos Estados Unidos. Instituto Socioambiental, [s. l.], 13 abr. 2015. Disponível em: https://www.socioambiental.org/pt-br/noticias-socioambientais/ yanomami-enterram-as-primeiras-amostras-de-sangue-repatriadas-dos-estados-unidos. Acesso em: 30 ago. 2020.

STENGERS, I. Cosmopolitiques, tome 1: la guerre des sciences. Paris: La Découverte, 2003. $2 \mathrm{v}$.

STENGERS, I. A proposição cosmopolítica. Revista do Instituto de Estudos Brasileiros, São Paulo, n. 69, p. 442-464, abr. 2018.

VIVEIROS DE CASTRO, E. Araweté: os deuses canibais. Rio de Janeiro: Jorge Zahar Editores: Anpocs, 1986.

VIVEIROS DE CASTRO, E. Perspectival anthropology and the method of controlled equivocation. Tipití: Journal of the Society for the Anthropology of Lowland South America, San Antonio, v. 2, n. 1, p. 3-22, 2004.

WORLD HEALTH ORGANIZATION. Infection prevention and control for the safe management of a dead body in the context of COVID-19: interim guidance, 24 March 2020. [S. l.]: WHO, 2020. Disponível em: https://apps.who.int/iris/handle/10665/331538. Acesso em: 27 ago. 2020.

Recebido: 31/08/2020 Aceito: 20/01/2021 | Received: 8/31/2020 Accepted:1/20/2021 